\title{
PRIORITAS PEMELIHARAAN IRIGASI SUB DAS KALI BRANTAS KOTA BATU MENGGUNAKAN METODE SIMPLE ADDITIVE WEIGHTING
}

\author{
Cholilu Rohman ${ }^{a}$ Umboro Lasminto ${ }^{\text {b }}$ dan Theresia Sri Sidharti ${ }^{c}$
}

\begin{abstract}
This paper presents the results of the study of one of the alternative decision support systems in determining the priority of irrigation maintenance. One of the obstacles in maintaining irrigation assets is the limited budget, hence the need for priority maintenance of irrigation. Batu City as an agricultural area, has not applied objective assessment criteria in determining the priority scale of irrigation asset maintenance to support the success of agriculture. Especially the irrigation area of Kali Brantas Sub Watershed which is the downstream area of Batu City, there are still many damaged irrigation assets infrastructure. This study aims to determine the priority of irrigation maintenance of Kali Brantas Sub Watershed Batu City. Analysis using Simple Additive Weighting method with the following stages: The assessment of each criterion directly in the field (Physical Condition, Functioning, Service Area and maintenance cost) according to Regulation of Minister of Public Works No. 13 / PRT / M / 2012, , determine the rating of each alternative match, normalization of alternative value of each criterion and ranking of normalization product with weight of importance. The result of the analysis shows that irrigation infrastructure which become the first priority in irrigation maintenance activity of Kali Brantas Sub Watershed Batu City is Genengan Dam. For second priority up to five consecutive are; Bend Beji I, Beji II, Ngukir Mranak II and Ngukir Mranak I Dam..
\end{abstract}

Keywords: Priority, irrigation, Simple Additive Weighting, Sub Watershed Kali Brantas, Batu City

\begin{abstract}
Abstrak: Makalah ini menyajikan hasil studi salah satu alternatif sistem pendukung keputusan dalam menentukan prioritas pemeliharaan irigasi. Salah satu kendala dalam pemeliharaan aset irigasi adalah terbatasnya anggaran, oleh sebab itu perlu adanya penentuan prioritas pemeliharaan irigasi. Kota Batu sebagai kawasan pertanian, belum menerapkan kriteria penilaian yang obyektif dalam menentukan skala prioritas pemeliharaan aset irigasi sebagai penunjang keberhasilan pertanian. Terutama daerah irigasi Sub DAS Kali Brantas yang merupakan daerah hilir Kota Batu, masih banyak prasarana aset irigasi yang mengalami kerusakan. Penelitian ini bertujuan untuk menentukan prioritas pemeliharaan irigasi Sub DAS Kali Brantas Kota Batu. Analisis menggunakan metode Simple Additive Weighting dengan tahapan sebagai berikut :Penilaian masing - masing kriteria secara langsung di lapangan (Kondisi Fisik, Keberfungsian, Luas Layanan dan biaya pemeliharaan) sesuai Peraturan Menteri Pekerjaan Umum Nomor 13/PRT/M/2012[1], menentukan bobot kepentingan kriteria, menentukan rating kecocokan setiap alternatif, normalisasi nilai alternatif masing - masing kriteria dan perankingan hasil perkalian normalisasi dengan bobot kepentingan. Hasil analisis menunjukkan bahwa prasarana irigasi yang menjadi prioritas pertama dalam kegiatan pemeliharaan irigasi Sub DAS Kali Brantas Kota Batu adalah Bendung Genengan. Untuk prioritas kedua hingga lima berturut - turut adalah ; Bendung Beji I, Bendung Beji II, Bendung Ngukir Mranak II dan Bendung Ngukir Mranak I.
\end{abstract}

Kata Kunci Prioritas, irigasi, Simple Additive Weighting, Sub DAS Kali Brantas, Kota Batu

\section{PENDAHULUAN}

Sesuai Visi Misi Kota Batu sebagai kawasan berbasis pertanian, maka menjadi keharusan bagi Pemerintah Daerah Kota Batu untuk memprioritaskan sektor pertanian dalam pembangunan ekonomi dan wilayah. Demi keberlanjutan sektor pertanian tidak dapat dipungkiri fungsi irigasi ini sangatlah penting. Irigasi biasanya dimanfaatkan oleh petani untuk penyediaan dan pengaturan air irigasi untuk menunjang pertanian. Pengelolaan aset irigasi pada hakekatnya merupakan proses manajemen yang terstruktur untuk perencanaan,

${ }^{a}$ Personnel at Dinas Pekerjaan Umum dan Penataan Ruang Kota Batu and a student in the Department of Civil Engineering, Sepuluh Nopember Institute of Technology (ITS), ITS Campus, Sukolilo, Surabaya 60111, Indonesia. Email: cole.rohman@yahoo.com

${ }^{b}$ Lecturer in the Department of Civil Engineering, Sepuluh Nopember Institute of Technology (ITS), ITS Campus, Sukolilo, Surabaya 60111, Indonesia. Email: umboro@ce.its.ac.id

${ }^{c}$ Lecturer in the Department of Civil Engineering, Sepuluh Nopember Institute of Technology (ITS), ITS Campus, Sukolilo, Surabaya 60111, Indonesia. Email: theresia_sri_sidharti@yahoo.com

Note. The manuscript for this paper was submitted for review and possible publication on January 08, 2018. This paper is part of the ITS Journal of Civil Engineering, Vol. 33, No. 2, November 2018. (C) ITS Journal of Civil Engineering, ISSN 2579-9029/2017. pemeliharaan dan pendanaan sistem irigasi guna mencapai tingkat pelayanan yang [2].

Faktor yang sering menjadi kendala dalam penyelenggaraan pemeliharaan dan perbaikan terhadap kerusakan biasanya adalah faktor biaya dan kesulitan dari Dinas Pekerjaan Umum dan Penataan Ruang Kota Batu dalam menentukan prioritas pemeliharaan irigasi, sehingga pemeliharaan menjadi tertunda dan kerusakan menjadi semakin buruk. Dengan demikian diperlukan metode yang dapat membantu para pengambil keputusan dalam menentukan prioritas pemeliharaan infrastruktur jaringan irigasi.

Tiap tahunnya ada sekitar 20 an aset irigasi yang harus diperbaiki oleh Dinas Pekerjaan Umum dan Penataan Ruang Kota Batu dari sekian banyak prasarana irigasi yang mengalami kerusakan. Saat ini, dalam menentukan skala prioritas pemeliharaan irigasi belum memiliki kriteria penilaian yang pasti. Hal ini memungkinkan adanya kriteria - kriteria yang tidak obyektif, sehingga hasil dari prioritas tersebut masih mudah di manipulasi oleh pihak - pihak tertentu.

Penanganan dan Prioritas perbaikan pada kenyataannya pengajuan dana untuk kepeluan pengelolaan jaringan irigasi dari tahun ke tahun tidak selalu terpenuhi sesuai dengan kebutuhan. Oleh karena itu 
Peraturan Menteri Pekerjaan UmumNomor 13/PRT/M/2012 telah mengamanatkan bahwa jenis penangan dan prioritas perbaikan perlu dibuat berdasarkan atas data : kondisi fisik jaringan irigasi, fungsi jaringan irigasi, luas layanan daerah irigasi dan biaya pemeliharaan jaringan irigasi.

Penentuan prioritas pemeliharaan jaringan irigasi dalam penelitian ini menggunakan metode pembobotan Simple Additive Weighting $(S A W)$. Decision Support System menggunakan metode $S A W$ ini dipilih karena metode ini dapat menentukan nilai bobot untuk semua atribut selanjutnya perankingan dari kriteria yang diinginkan berdasarkan penilaian langsung di lapangan, mudah dan cepat perhitungannya dan tanpa memerlukan uji konsistensi [3].

\section{LOKASI PENELITIAN}

Penelitian ini dilakukan pada Daerah Irigasi Sub DAS Kali Brantas, yang sebagian besar berada di Kecamatan Junrejo Kota Batu Propinsi Jawa Timur. Daerah irigasi lokasi penelitian Sub DAS Kali Brantas Kota Batu ada 7 (tujuh) daerah irigasi dengan total luas layanan 157,1 Ha, dengan rincian sebagai berikut : DI Genengan 18,2 Ha, DI Beji I 22,2 Ha, DI Beji II 3,4 Ha, DI Jurang Jero I 8 Ha, DI Jurang Jero II 6,9 Ha, DI Ngukir Mranak I 45,8 Ha dan DI Ngukir Mranak II 52,6 Ha.

\section{KEBUTUHAN DATA}

Data yang dibutuhkan dalam menentukan Prioritas pemeliharaan irigasi dengan menggunakan metode Simple Additive Weighting, adalah sebagai berikut:

1. Data Kriteria

Data kriteria berisi kode, nama, atribut,bobot dan sumber data. Bobot kriteria menentukan seberapa penting kriteria tersebut. Atribut kriteria terdiri dari benefit atau cost, dimana benefit artinya semakin besar nilainya semakin prioritas, sedangkan cost semakin kecil nilainya semakin prioritas. Data kriteria seperti tertera pada Tabel 1.

Tabel 1. Kebutuhan Data Penelitian

\begin{tabular}{|c|c|c|c|c|}
\hline Kode & $\begin{array}{c}\text { Nama } \\
\text { Kriteria }\end{array}$ & Atribut & Bobot & $\begin{array}{c}\text { Sumber } \\
\text { Data }\end{array}$ \\
\hline $\mathrm{C} 1$ & $\begin{array}{l}\text { Kondisi } \\
\text { Fisik Aset } \\
\text { Irigasi }\end{array}$ & benefit & Wk & $\begin{array}{l}\text { Penilaian } \\
\text { langsung secara } \\
\text { visual dan } \\
\text { pengukuran }\end{array}$ \\
\hline $\mathrm{C} 2$ & $\begin{array}{l}\text { Fungsi } \\
\text { Aset } \\
\text { Irigasi }\end{array}$ & benefit & Wf & $\begin{array}{l}\text { Penilaian } \\
\text { parameter } \\
\text { variabel fungsi }\end{array}$ \\
\hline $\mathrm{C} 3$ & $\begin{array}{l}\text { Luas } \\
\text { Layanan } \\
\text { Daerah } \\
\text { Irigasi }\end{array}$ & benefit & $\mathrm{Wl}$ & $\begin{array}{l}\text { Data Sekunder } \\
\text { dari Dinas } \\
\text { Pertanian Kota } \\
\text { Batu }\end{array}$ \\
\hline $\mathrm{C} 4$ & $\begin{array}{l}\text { Estimasi } \\
\text { Biaya } \\
\text { Pemelihar } \\
\text { aan Irigasi }\end{array}$ & cost & $\mathrm{Wb}$ & $\begin{array}{l}\text { Perhitungan biaya } \\
\text { berdasarkan } \\
\text { tingkat kerusakan }\end{array}$ \\
\hline
\end{tabular}

2. Data Alternatif

Data alternatif merupakan alternatif yang akan dihitung nilainya dan dipilih sebagai alternatif terbaik. Data alternatif biasanya disimbolkan A berisi kode atau nama aset irigasi.

\section{METODOLOGI}

Metode Simple Additive Weighting ( $S A W$ ) sering juga dikenal istilah metode penjumlahan terbobot [4]. Tahapan analisis metode Simple Additive Weighting seperti terlihat pada Gambar 1 berikut :

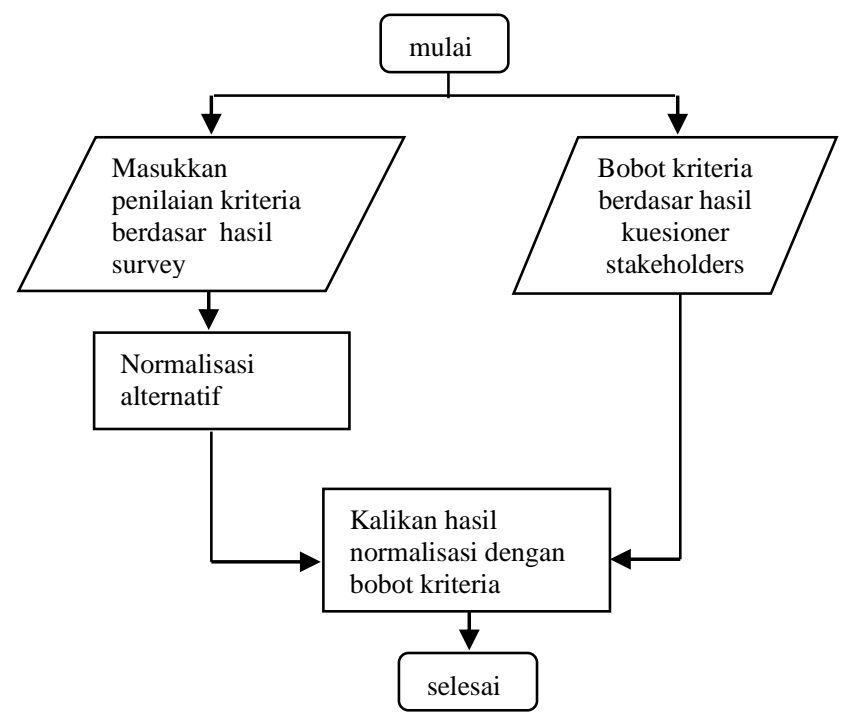

Gambar 1. Diagram Alir Metode SAW

Langkah - langkah penentuan prioritas pemeliharaan irigasi menggunakan metode $S A W$ adalah sebagai berikut:

1. Menentukan bobot kepentingan dengan dilakukan kuesioner kepada stakeholder Sub DAS Kali Brantas Kota Batu tentang bobot kepentingan masing masing kriteria. Bobot kepentingan kriteria ditunjukkan pada Tabel 2.

Tabel 2. Bobot Kepentingan Kriteria

\begin{tabular}{ll}
\hline Kepentingan & Skor \\
\hline Sangat Penting & 3 \\
\hline Penting & 2 \\
\hline Cukup Penting & 1 \\
\hline
\end{tabular}

2. Menentukan rating kecocokan setiap altenatif pada setiap kriteria.

3. Melakukan proses normalisasi matrik keputusan (X) ke suatu skala yang dapat di perbandingkan dengan semua rating alternatif yang ada. Matrik ternormalisasi $\mathrm{R}$ diperoleh dari persamaan

$$
\begin{aligned}
& \mathrm{R}_{\mathrm{ij}}=\frac{\mathrm{X}_{\overline{\mathrm{y}}}}{\operatorname{Max} \mathrm{X}_{\overline{\mathrm{y}}}} \quad \text { Jika j ialah benefit } \\
& \mathrm{R}_{\mathrm{ij}}=\frac{\operatorname{Min} \mathrm{X}_{\text {ज }}}{\mathrm{X}_{\mathrm{v}}} \quad \text { Jikaj ialah cost }
\end{aligned}
$$

4. Hasil akhir diperoleh dari proses perankingan yaitu penjumlahan dari perkalian matriks ternormalisasi $\mathrm{R}$ dengan vektor bobot sehingga diperoleh nilai terbesar yang dipilih sebagai prioritas pemeliharaan irigasi, dengan rumus : 


$$
A_{i}=\sum_{j=1}^{n} W_{j} R_{i j}
$$

Keterangan:

$\mathrm{Ai}=$ Skor alternatif

$\mathrm{Wj}=$ Bobot kriteria

Rij = Nilai normalisasi

Untuk menentuan prioritas pemeliharaan aset irigasi terlebih dahulu dilakukan beberapa penilaian kriteria berdasarkan hasil pengamatan langsung secara visual dan pengukuran, dengan bobot komponen irigasi pada Tabel 3 berikut :

Tabel 3. Bobot Komponen Irigasi (Cij)

\begin{tabular}{|c|c|c|}
\hline No & Prasarana Irigasi & Bobot (\%) \\
\hline \multirow[t]{2}{*}{ I } & Bendung & 35 \\
\hline & Bangunan Pengambilan & 12 \\
\hline & - $\quad$ Pintu / pintu banjir & 5 \\
\hline & - $\quad$ Endapan / Lumpur & 3 \\
\hline & - $\quad$ Pengukur Debit & 3 \\
\hline & - Papan Eksploitasi & 1 \\
\hline \multirow[t]{3}{*}{2} & Bangunan Penguras & 6 \\
\hline & - $\quad$ Pintu & 4 \\
\hline & - $\quad$ Endapan / Lumpur & 2 \\
\hline \multirow[t]{4}{*}{3} & Tubuh bendung & 10 \\
\hline & - $\quad$ mercu & 5 \\
\hline & - $\quad$ Ruang Olakan & 4 \\
\hline & - Papan Skala & 1 \\
\hline \multirow[t]{3}{*}{4} & Sayap & 4 \\
\hline & - $\quad$ sayap & 2 \\
\hline & - Koperan & 2 \\
\hline \multirow[t]{4}{*}{5} & Bangunan Pelengkap Bendung & 3 \\
\hline & - Jembatan Utama & 1 \\
\hline & - $\quad$ Rumah PPA / Gedung & 1 \\
\hline & - $\quad$ Gawat Banjir & 1 \\
\hline II & Saluran Pembawa & 25 \\
\hline 1 & - $\quad$ Erosi dan atau sedimentasi & 5 \\
\hline 2 & - $\quad$ Profil Saluran & 12 \\
\hline 3 & Bocoran & 8 \\
\hline III & Bangunan Bagi / Sadap & 25 \\
\hline 1 & - $\quad$ Pintu Sadap dan Pengatur & 12 \\
\hline 2 & Bangunan Pengukur Debit & 5 \\
\hline 3 & Tubuh Bangunan & 8 \\
\hline IV & Saluran Pembuang & 10 \\
\hline 1 & Erosi dan Sedimentasi & 6 \\
\hline 2 & Profil Saluran & 4 \\
\hline $\mathrm{V}$ & Bangunan Pada Saluran & 5 \\
\hline 1 & - $\quad$ Pintu Pengatur & 2 \\
\hline 2 & - $\quad$ Tubuh Bangunan & 3 \\
\hline & Total & 100 \\
\hline
\end{tabular}

Sumber : [5]

1. Penilaian Kondisi Fisik Jaringan Irigasi

Metode pengumpulan data dengan Survey / pengamatan langsung secara visual kondisi eksisting dibandingkan desain awal di lapangan untuk mengidentifikasikan kondisi fisik aset irigasi. Perhitungan nilai kondisi fisik infrastruktur dapat diketahui dengan cara berikut :

$$
\mathrm{K}_{\mathrm{ij}}=\frac{\text { Luas rusak }}{\text { Luas total }} \times \mathrm{C}_{\mathrm{ij}}
$$

Dimana :

$K i j=$ Nilai kondisi bagian komponen

$C i j=$ Bobot bagian komponen
2. Penilaian Keberfungsian Jaringan Irigasi

Metode pengumpulan data dengan Survey / pengamatan langsung di lapangan untuk mengidentifikasikan fungsi aset irigasi. Bobot penilaian fungsi infrastruktur irigasi dapat diklasifikasikan seperti yang terlihat pada Tabel 4 berikut :

Tabel 4. Bobot Fungsi Komponen (FCij)

\begin{tabular}{lcc}
\hline No & Keberfungsian & Nilai \\
\hline 1. & Berfungsi baik & $<10 \%$ \\
\hline 2. & Masih berfungsi dengan kendala & $10-20 \%$ \\
\hline 3. & Tidak dapat berfungsi dengan baik & $21-40 \%$ \\
\hline 4. & Sama sekali tidak dapat berfungsi & $>40 \%$ \\
\hline
\end{tabular}

Sumber : [1]

Variabel yang diamati dalam penilaian keberfungsian aset irigasi berdasarkan pedoman subdit Bina Program Ditjen Sumber Daya Air dapat dilihat pada Tabel 5 berikut :

\begin{tabular}{|c|c|}
\hline No & Variabel \\
\hline \multicolumn{2}{|r|}{ Pintu } \\
\hline 1. & Pengoperasian secara mekanis dan hidrolis \\
\hline 2. & Cat anti karat \\
\hline 3. & Pelumas gigi dan ulir \\
\hline 4. & Kebocoran daun pintu \\
\hline \multicolumn{2}{|r|}{ Pengukur Debit } \\
\hline 1. & Fungsi sarana pengukuran \\
\hline 2. & Tabel pembacaan debit \\
\hline 3. & Papan duga (peilschaal) \\
\hline \multicolumn{2}{|r|}{ Tubuh Bangunan } \\
\hline 1. & $\begin{array}{l}\text { Retak / pecah yang membahayakan konstruksi dan } \\
\text { fungsi bangunan }\end{array}$ \\
\hline 2. & Gerusan di bangunan \\
\hline 3. & Penurunan tubuh bangunan \\
\hline \multicolumn{2}{|r|}{ Sedimentasi } \\
\hline 1. & Endapan diukur tinggi ambang pintu \\
\hline 2. & Pengurasan berkala \\
\hline
\end{tabular}

Tabel 5. Variabel Fungsi Komponen Irigasi

Selanjutnya dilakukan penilaian keberfungsian aset irigasi dengan rumus sebagai berikut :

$$
\mathrm{F}_{\mathrm{ij}}=\frac{F C_{\mathrm{ij}}}{100} \mathrm{x} \mathrm{C}_{\mathrm{fj}}
$$

Dimana :

$F i j=$ Nilai fungsi bagian komponen

$\mathrm{Cij}=$ Bobot bagian komponen

$\mathrm{FCij}=$ Bobot fungsi bagian komponen

3. Luas Layanan Irigasi

Dalam penelitian ini, pengumpulan data langsung dari data sekunder yang didapat dari Dinas Pertanian Kota Batu Tahun 2017[6].

4. Estimasi Biaya Pemeliharaan

Rencana anggaran biaya pemeliharaan irigasi menggunakan acuan analisa harga satuan Kota Batu[7] dengan perhitungan sebagai berikut: Harga $=$ Harga satuan $\mathrm{x}$ Volume 


\section{ANALISIS DAN PEMBAHASAN}

1. Penilaian Kriteria

a. Penilaian kondisi fisik prasarana irigasi

Penilaian kerusakan kondisi fisik prasarana irigasi dilakukan dengan cara pengamatan visual dan pengukuran. Rekapitulasi Penilaian kerusakan kondisi fisik aset irigasi Sub DAS Kali Brantas Kota Batu dapat dilihat pada Gambar 2.

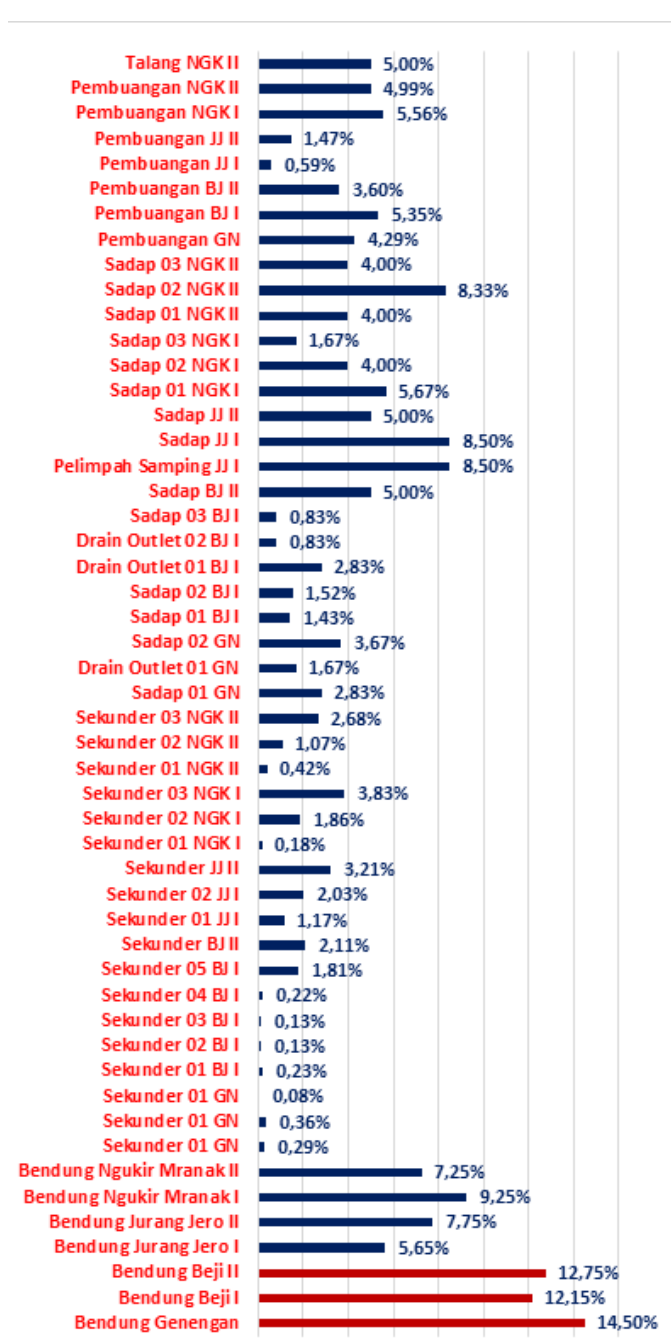

Gambar 2. Penilaian Kerusakan Kondisi

Berdasarkan hasil penilaian diatas, dapat disimpulkan bahwa aset irigasi yang mengalami kerusakan ringan adalah Bendung Genengan, Bendung Beji I dan Bendung Beji II. Hal ini dikarenakan nilai aset irigasi tersebut diantara 10 $-20 \%$, sehingga perlu pemeliharaan rutin untuk mengoptimalkan kondisi aset irigasi tersebut.

b. Penilaian keberfungsian prasarana irigasi

Penilaian ketidak berfungsian aset irigasi diperoleh dengan cara membandingkan parameter variabel fungsi dengan keadaan di lapangan.

Variabel fungsi yang perlu diamati adalah pintu, pengukur debit, tubuh bangunan dan sedimentasi. Rekapitulasi penilaian fungsi Sub DAS Kali Brantas Kota Batu dapat dilihat pada Gambar 3.

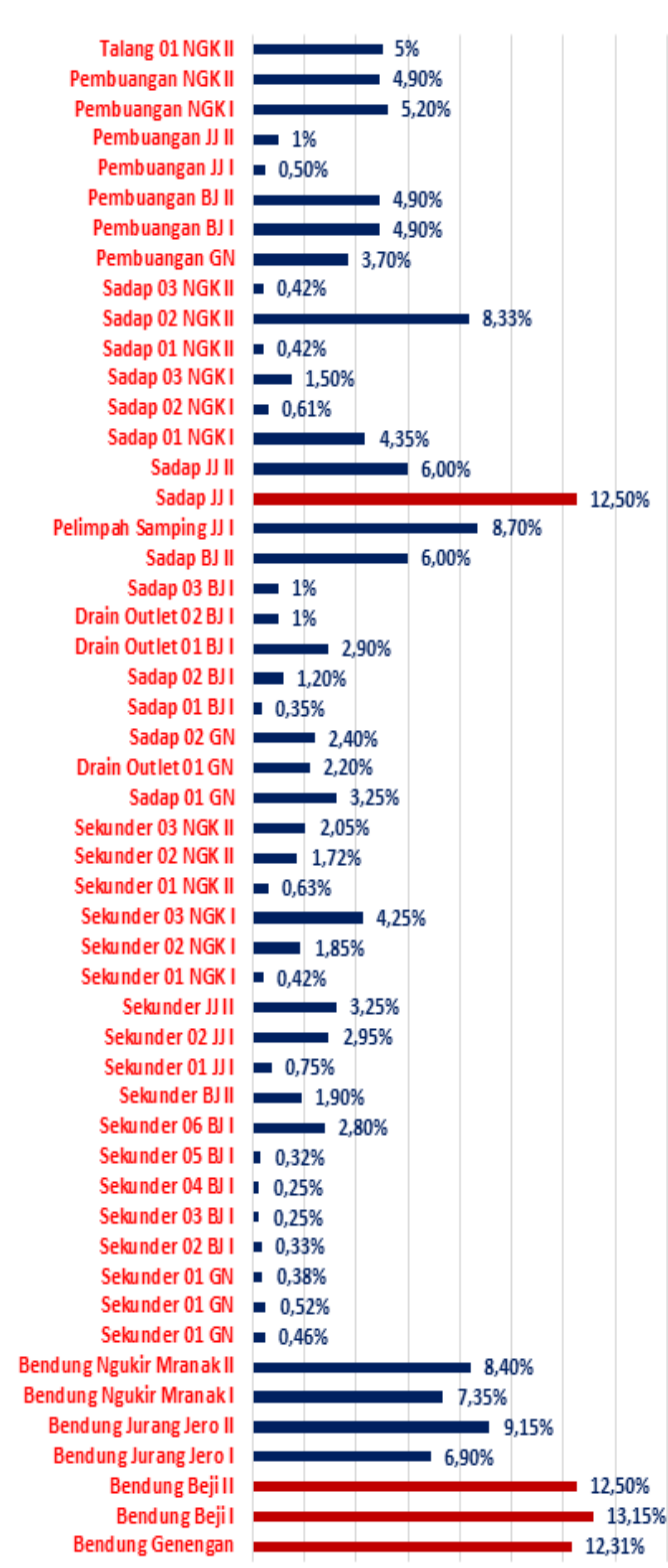

Gambar 3. Penilaian Ketidakberfungsian

Berdasarkan hasil penilaian diatas, dapat disimpulkan bahwa aset irigasi keberfungsian yang megalami kendala adalah Bendung Beji I, Bendung Beji II, Bendung Genengan dan Banguan Sadap Jurang Jero I. Hal ini dikarenakan nilai aset irigasi tersebut diantara 10 $-20 \%$, sehingga perlu pemeliharaan rutin untuk mengoptimalkan keberfungsian aset irigasi tersebut.

c. Penilaian biaya pemeliharaan

Selanjutnya dilakukan penilaian biaya pemeliharaan berdasarkan tingkat kerusakan aset irigasi dengan analisa harga satuan Kota Batu. Rekapitulasi penilaian biaya ditunjukkan pada Tabel 6 berikut : 
Tabel 6. Penilaian Biaya Pemeliharaan

\begin{tabular}{|c|c|c|}
\hline No & Prasarana Irigasi & Biaya \\
\hline 1 & Bendung Genengan & $27.619 .000,00$ \\
\hline 2 & Bendung Beji I & $409.000,00$ \\
\hline 3 & Bendung Beji II & $648.000,00$ \\
\hline 4 & Bendung Jurang Jero I & $1.913 .000,00$ \\
\hline 5 & Bendung Jurang Jero II & $688.000,00$ \\
\hline 6 & Bendung Ngukir Mranak I & $554.000,00$ \\
\hline 7 & Bendung Ngukir Mranak II & $471.000,00$ \\
\hline 8 & Sekunder 01 GN & $7.722 .000,00$ \\
\hline 9 & Sekunder $02 \mathrm{GN}$ & $6.529 .000,00$ \\
\hline 10 & Sekunder 03 GN & $653.000,00$ \\
\hline 11 & Sekunder 01 BJ I & $13.008 .000,00$ \\
\hline 12 & Sekunder 02 BJ I & $850.000,00$ \\
\hline 13 & Sekunder 03 BJ I & $1.669 .000,00$ \\
\hline 14 & Sekunder 04 BJ I & $12.316 .000,00$ \\
\hline 15 & Sekunder 05 BJ I & $531.231 .000,00$ \\
\hline 16 & Sekunder BJ II & $5.072 .000,00$ \\
\hline 17 & Sekunder 01 JJ I & $16.232 .000,00$ \\
\hline 18 & Sekunder 02 JJ I & $156.007 .000,00$ \\
\hline 19 & Sekunder JJ II & $59.379 .000,00$ \\
\hline 20 & Sekunder 01 NGK I & $1.931 .000,00$ \\
\hline 21 & Sekunder 02 NGK I & $2.551 .259 .000,00$ \\
\hline 22 & Sekunder 03 NGK I & $1.516 .174 .000,00$ \\
\hline 23 & Sekunder 01 NGK II & $44.607 .000,00$ \\
\hline 24 & Sekunder 02 NGK II & $305.231 .000,00$ \\
\hline 25 & Sekunder 03 NGK II & $695.626 .000,00$ \\
\hline 26 & Sadap 01 GN & $2.109 .000,00$ \\
\hline 27 & Drain Outlet 01 GN & $924.000,00$ \\
\hline 28 & Sadap 02 GN & $745.000,00$ \\
\hline 29 & Sadap 01 BJ I & $2.741 .000,00$ \\
\hline 30 & Sadap 02 BJ I & $1.622 .000,00$ \\
\hline 31 & Drain Outlet 01 BJ I & $1.130 .000,00$ \\
\hline 32 & Drain Outlet 02 BJ I & $1.130 .000,00$ \\
\hline 33 & Sadap 04 BJ I & $1.130 .000,00$ \\
\hline 34 & Sadap BJ II & $3.800 .000,00$ \\
\hline 35 & Pelimpah Samping JJ I & $2.861 .000,00$ \\
\hline 36 & Sadap JJ I & $2.385 .000,00$ \\
\hline 37 & Sadap JJ II & $3.230 .000,00$ \\
\hline 38 & Sadap 01 NGK I & $3.543 .000,00$ \\
\hline 39 & Sadap 02 NGK I & $70.000,00$ \\
\hline 40 & Sadap 03 NGK I & $953.000,00$ \\
\hline 41 & Sadap 01 NGK II & $60.000,00$ \\
\hline 42 & Sadap 02 NGK II & $2.850 .000,00$ \\
\hline 43 & Sadap 03 NGK II & $156.000,00$ \\
\hline 44 & Pembuangan GN & $131.688 .000,00$ \\
\hline 45 & Pembuangan BJ I & $395.124 .000,00$ \\
\hline 46 & Pembuangan BJ II & $184.064 .000,00$ \\
\hline 47 & Pembuangan JJ I & $7.733 .000,00$ \\
\hline 48 & Pembuangan JJ II & $12.823 .000,00$ \\
\hline 49 & Pembuangan NGK I & $247.054 .000,00$ \\
\hline 50 & Pembuangan NGK II & $180.933 .000,00$ \\
\hline 51 & Talang & $112.563 .000,00$ \\
\hline
\end{tabular}

Tabel diatas menunjukkan bahwa biaya pemeliharaan terendah adalah bangunan sadap 01 Ngukir Mranak II sebesar Rp. 60.000,00 dengan pekerjaan pengecatan pintu sadap. Sedangkan biaya pemeliharaan terbesar adalah saluran sekunder 02 Ngukir Mranak II sebesar Rp. 2.551.259.000,00 dengan pembangunan saluran sepanjang 1796 meter.

2. Penentuan Bobot Kepentingan

Penentuan bobot kepentingan kriteria prioritas pemeliharaan irigasi Sub DAS Kali Brantas Kota
Batu didahului dengan pemetaan stakeholders, terbagi dalam tiga kelompok, yaitu :

a. Stakeholder primer, dalam hal ini petani yang sangat tergantung oleh adanya pasokan air dari Sub DAS Kali Brantas Kota Batu.

b. Stakeholder sekunder, Kecamatan Junrejo yang memiliki kepedulian sehingga mereka turut mempengaruhi keputusan.

c. Stakeholder kunci, Dinas Pekerjaan Umum dan Penataan Ruang Kota Batu yang memiliki wewenang secara legal dalam mengambil keputusan.

Berdasarkan pemetaan stakeholder diatas, maka dapat dipilih responden stakeholders dalam menentukan bobot kepentingan masing - masing kriteria, sebagai berikut :

a. Petani, sebanyak 3 responden

b. Kecamatan Junrejo, sebanyak 1 responden

c. Dinas Pekerjaan Umum dan Penataan Ruang Kota batu, sebanyak 6 responden

Rekapitulasi hasil kuesioner bobot kepentingan dapat dilihat pada Tabel 7.

Tabel 7. Kuesioner Bobot Kepentingan

\begin{tabular}{lccc}
\hline \multirow{2}{*}{ Kriteria } & \multicolumn{3}{c}{ Kepentingan } \\
\cline { 2 - 4 } & $\begin{array}{c}\text { Sangat } \\
\text { Penting }\end{array}$ & Penting & $\begin{array}{c}\text { Cukup } \\
\text { Penting }\end{array}$ \\
\hline Kondisi fisik aset irigasi & 10 & & \\
\hline Keberfungsian aset irigasi & 7 & 3 & \\
\hline Luas layanan irigasi & & 6 & 4 \\
\hline Biaya pemeliharaan irigasi & & 3 & 7 \\
\hline
\end{tabular}

Dari data yang didapat diatas, kemudian diolah dengan cara mengkalikan setiap point jawaban dengan bobot yang sudah ditentukan dengan skala likert. Maka hasil perhitungan jawaban responden (Stakeholders) sebagai berikut :

a. Kriteria Kondisi Fisik Aset Irigasi

$\checkmark$ Responden menjawab sangat penting (10) $=3 \times 10=30$

b. Kriteria Keberfungsian Aset Irigasi

$\checkmark \quad$ Responden menjawab sangat penting (7) $=3 \times 7=21$

$\checkmark \quad$ Responden menjawab penting (3) $=2 \times 3=6$

c. Kriteria Luas Layanan Irigasi

$\checkmark \quad$ Responden menjawab penting (6) $=2 \times 6=12$

$\checkmark \quad$ Responden menjawab cukup penting (4) $=1 \times 4=4$

d. Kriteria Biaya Pemeliharaan Irigasi

$\checkmark \quad$ Responden menjawab penting (3) $=2 \times 3=6$

$\checkmark \quad$ Responden menjawab cukup penting (7) $=1 \times 7=7$

Total Skor $=30+21+6+12+4+6+7=86$ Sehingga diperoleh bobot kepentingan masing masing kriteria sebagai berikut :

a. Bobot kriteria kondisi fisik $=30 / 86=0,35$

b. Bobot kriteria keberfungsian $=27 / 86=0,31$

c. Bobot kriteria luas layanan $=16 / 86=0,19$

d. Bobot kriteria biaya $=13 / 86=0,15$ 
3. Penentuan Rating Kecocokan

Langkah selanjutnya adalah Membuat rating kecocokan alternatif terhadap kriteria, pada penelitian ini menggunakan 7 daerah irigasi yang akan digunakan sebagai sampel. Data nilai alternatif terhadap kriteria sesuai hasil penilaian kriteria seperti yang tertera pada Tabel 8 berikut :

Tabel 8. Rating Kecocokan Alternatif Terhadap Kriteria

\begin{tabular}{|c|c|c|c|c|c|}
\hline \multirow[b]{2}{*}{ No } & \multirow[b]{2}{*}{ Alternatif } & \multirow{2}{*}{$\begin{array}{c}\text { Kriteria } 1 \\
\text { Kondisi Fisik (ck) }\end{array}$} & \multirow{2}{*}{\begin{tabular}{|l|} 
Kriteria 2 \\
Fungsi (cf)
\end{tabular}} & \multirow{2}{*}{$\begin{array}{c}\text { Kriteria } 3 \\
\begin{array}{c}\text { Luas Layanan } \\
\text { (cl) }\end{array} \\
\end{array}$} & \multirow{2}{*}{\begin{tabular}{|l|} 
Kriteria 4 \\
Biaya (cb)
\end{tabular}} \\
\hline & & & & & \\
\hline 1 & Bendung Genengan & 14,50 & 12,31 & 18,2 & $27.619 .000,00$ \\
\hline 2 & Bendung Beji I & 12,15 & 13,15 & 22,2 & $409.000,00$ \\
\hline 3 & Bendung Beji II & 12,75 & 12,50 & 3,4 & $648.000,00$ \\
\hline 4 & Bendung Jurang Jero I & 5,65 & 6,90 & 8 & $1.913 .000,00$ \\
\hline 5 & Bendung Jurang Jero II & 7,75 & 9,15 & 6,9 & $688.000,00$ \\
\hline 6 & Bendung Ngukir Mranak I & 9,25 & 7,35 & 45,8 & $554.000,00$ \\
\hline 7 & Bendung Ngukir Mranak II & 7,25 & 8,40 & 52,6 & $471.000,00$ \\
\hline 8 & Sekunder $01 \mathrm{GN}$ & 0,29 & 0,46 & 16 & $7.722 .000,00$ \\
\hline 9 & Sekunder 02 GN & 0,36 & 0,52 & 1 & $6.529 .000,00$ \\
\hline 10 & Sekunder 03 GN & 0,08 & 0,38 & 1,2 & $653.000,00$ \\
\hline 11 & Sekunder 01 BJ I & 0,23 & 0,33 & 4,2 & $13.008 .000,00$ \\
\hline 12 & Sekunder 02 BJ I & 0,13 & 0,25 & 4 & $850.000,00$ \\
\hline 13 & Sekunder 03 BJ I & 0,13 & 0,25 & 1,7 & $1.669 .000,00$ \\
\hline 14 & Sekunder 04 BJ I & 0,22 & 0,32 & 9,6 & $12.316 .000,00$ \\
\hline 15 & Sekunder 05 BJ I & 1,81 & 2,80 & 2,7 & $531.231 .000,00$ \\
\hline 16 & Sekunder BJ II & 2,11 & 1,90 & 3,4 & $5.072 .000,00$ \\
\hline 17 & Sekunder $01 \mathrm{JJ} \mathrm{I}$ & 1,17 & 0,75 & 2,5 & $16.232 .000,00$ \\
\hline 18 & Sekunder $02 \mathrm{JJ} \mathrm{I}$ & 2,03 & 2,95 & 5,5 & $156.007 .000,00$ \\
\hline 19 & Sekunder JJ II & 3,21 & 3,25 & 6,9 & $59.379 .000,00$ \\
\hline 20 & Sekunder 01 NGK I & 0,18 & 0,42 & 8,8 & $1.931 .000,00$ \\
\hline 21 & Sekunder 02 NGK I & 1,86 & 1,85 & 19 & $2.551 .259 .000,00$ \\
\hline 22 & Sekunder 03 NGK I & 3,83 & 4,25 & 18 & 1.516.174.000,00 \\
\hline 23 & Sekunder 01 NGK II & 0,42 & 0,63 & 9,6 & $44.607 .000,00$ \\
\hline 24 & Sekunder 02 NGK II & 1,07 & 1,72 & 26 & $305.231 .000,00$ \\
\hline 25 & Sekunder 03 NGK II & 2,68 & 2,05 & 17 & $695.626 .000,00$ \\
\hline 26 & Sadap $01 \mathrm{GN}$ & 2,83 & 3,25 & 16 & $2.109 .000,00$ \\
\hline 27 & Drain Outlet $01 \mathrm{GN}$ & 1,67 & 2,20 & 1 & $924.000,00$ \\
\hline 28 & Sadap 02 GN & 3,67 & 2,40 & 1,2 & $745.000,00$ \\
\hline 29 & Sadap 01 BJ I & 1,43 & 0,35 & 4,2 & $2.741 .000,00$ \\
\hline 30 & Sadap 02 BJ I & 1,52 & 1,20 & 4 & $1.622 .000,00$ \\
\hline 31 & Drain Outlet 01 BJ I & 2,83 & 2,90 & 1,7 & $1.130 .000,00$ \\
\hline 32 & Drain Outlet 02 BJ I & 0,83 & 1,00 & 9,6 & $1.130 .000,00$ \\
\hline 33 & Sadap 03 BJ I & 0,83 & 1,00 & 2,7 & $1.130 .000,00$ \\
\hline 34 & Sadap BJ II & 5,00 & 6,00 & 3,4 & $3.800 .000,00$ \\
\hline 35 & Pelimpah Samping JJ I & 8,50 & 8,70 & 2,5 & $2.861 .000,00$ \\
\hline 36 & Sadap JJ I & 8,50 & 12,50 & 5,5 & $2.385 .000,00$ \\
\hline 37 & Sadap JJ II & 5,00 & 6,00 & 6,9 & $3.230 .000,00$ \\
\hline 38 & Sadap 01 NGK I & 5,67 & 4,35 & 8,8 & $3.543 .000,00$ \\
\hline 39 & Sadap 02 NGK I & 4,00 & 0,61 & 19 & $70.000,00$ \\
\hline 40 & Sadap 03 NGK I & 1,67 & 1,50 & 18 & $953.000,00$ \\
\hline 41 & Sadap 01 NGK II & 4,00 & 0,42 & 9,6 & $60.000,00$ \\
\hline 42 & Sadap 02 NGK II & 8,33 & 8,33 & 26 & $2.850 .000,00$ \\
\hline 43 & Sadap 03 NGK II & 4,00 & 0,42 & 17 & $156.000,00$ \\
\hline 44 & Pembuangan GN & 4,29 & 3,70 & 0 & $131.688 .000,00$ \\
\hline 45 & Pembuangan BJ I & 5,35 & 4,90 & 0 & $395.124 .000,00$ \\
\hline 46 & Pembuangan BJ II & 3,60 & 4,90 & 0 & $184.064 .000,00$ \\
\hline 47 & Pembuangan JJ I & 0,59 & 0,50 & 0 & $7.733 .000,00$ \\
\hline 48 & Pembuangan JJ II & 1,47 & 1,00 & 0 & $12.823 .000,00$ \\
\hline 49 & Pembuangan NGK I & 5,56 & 5,20 & 0 & $247.054 .000,00$ \\
\hline 50 & Pembuangan NGK II & 4,99 & 4,90 & 0 & $180.933 .000,00$ \\
\hline 51 & Talang 1 NGK I & 5,00 & 5,00 & 0,7 & $112.563 .000,00$ \\
\hline & Maksimum & 14,50 & 13,15 & 52,6 & \\
\hline & Minimum & & & & $60.000,00$ \\
\hline
\end{tabular}


4. Normalisasi

Langkah selanjutnya adalah melakukan normalisasi dengan matrik keputusan (X) ke suatu skala yang dapat di perbandingkan dengan semua rating alternatif yang ada. Jika fungsi kriteria benefit, maka nilai tersebut dibagi dengan nilai paling besar diantara nilai kriteria tersebut. Jika kriteria tersebut dalam fungsi cost maka nilai minimum dari kriteria dibagi dengan nilai alternatifnya, sehingga diperoleh nilai normalisasi pada Tabel 9 .

Tabel 9. Normalisasi Nilai Aternatif Setiap Kriteria

\begin{tabular}{|c|c|c|c|c|c|c|c|c|c|}
\hline \multirow[b]{2}{*}{ No } & \multirow{2}{*}{ Alternatif } & \multirow[b]{2}{*}{ ck } & \multirow{2}{*}{$\begin{array}{c}\mathrm{R}(\mathrm{ck}) \\
\mathrm{ck} / \mathrm{max} \text { ck }\end{array}$} & \multirow[b]{2}{*}{ cf } & \multirow{2}{*}{$\begin{array}{c}\mathbf{R}(\mathbf{c f}) \\
\text { cf/max cf }\end{array}$} & \multirow[b]{2}{*}{ cl } & \multirow{2}{*}{$\begin{array}{c}\mathbf{R}(\mathbf{c l}) \\
\mathbf{c l} / \max \\
\mathbf{c l}\end{array}$} & \multirow[b]{2}{*}{ cb } & \multirow{2}{*}{$\begin{array}{c}\mathbf{R}(\mathbf{c b}) \\
\min \mathrm{cb} / \mathrm{cl}\end{array}$} \\
\hline & & & & & & & & & \\
\hline 1 & Bendung Genengan & 14,50 & 1,00 & 12,31 & 0,94 & 18,2 & 0,35 & $27.619 .000,00$ & 0,00217 \\
\hline 2 & Bendung Beji I & 12,15 & 0,84 & 13,15 & 1,00 & 22,2 & 0,42 & $409.000,00$ & 0,14670 \\
\hline 3 & Bendung Beji II & 12,75 & 0,88 & 12,50 & 0,95 & 3,4 & 0,06 & $648.000,00$ & 0,09259 \\
\hline 4 & Bendung Jurang Jero I & 5,65 & 0,39 & 6,90 & 0,52 & 8 & 0,15 & $1.913 .000,00$ & 0,03136 \\
\hline 5 & Bendung Jurang Jero II & 7,75 & 0,53 & 9,15 & 0,70 & 6,9 & 0,13 & $688.000,00$ & 0,08721 \\
\hline 6 & Bendung Ngukir Mranak I & 9,25 & 0,64 & 7,35 & 0,56 & 45,8 & 0,87 & $554.000,00$ & 0,10830 \\
\hline 7 & Bendung Ngukir Mranak II & 7,25 & 0,50 & 8,40 & 0,64 & 52,6 & 1,00 & $471.000,00$ & 0,12739 \\
\hline 8 & Sekunder $01 \mathrm{GN}$ & 0,29 & 0,02 & 0,46 & 0,04 & 16 & 0,30 & $7.722 .000,00$ & 0,00777 \\
\hline 9 & Sekunder $02 \mathrm{GN}$ & 0,36 & 0,02 & 0,52 & 0,04 & 1 & 0,02 & $6.529 .000,00$ & 0,00919 \\
\hline 10 & Sekunder 03 GN & 0,08 & 0,01 & 0,38 & 0,03 & 1,2 & 0,02 & $653.000,00$ & 0,09188 \\
\hline 11 & Sekunder 01 BJ I & 0,23 & 0,02 & 0,33 & 0,03 & 4,2 & 0,08 & $13.008 .000,00$ & 0,00461 \\
\hline 12 & Sekunder 02 BJ I & 0,13 & 0,01 & 0,25 & 0,02 & 4 & 0,08 & $850.000,00$ & 0,07059 \\
\hline 13 & Sekunder 03 BJ I & 0,13 & 0,01 & 0,25 & 0,02 & 1,7 & 0,03 & $1.669 .000,00$ & 0,03595 \\
\hline 14 & Sekunder 04 BJ I & 0,22 & 0,02 & 0,32 & 0,02 & 9,6 & 0,18 & $12.316 .000,00$ & 0,00487 \\
\hline 15 & Sekunder 05 BJ I & 1,81 & 0,12 & 2,80 & 0,21 & 2,7 & 0,05 & $531.231 .000,00$ & 0,00011 \\
\hline 16 & Sekunder BJ II & 2,11 & 0,15 & 1,90 & 0,14 & 3,4 & 0,06 & $5.072 .000,00$ & 0,01183 \\
\hline 17 & Sekunder $01 \mathrm{JJ}$ I & 1,17 & 0,08 & 0,75 & 0,06 & 2,5 & 0,05 & $16.232 .000,00$ & 0,00370 \\
\hline 18 & Sekunder $02 \mathrm{JJ} \mathrm{I}$ & 2,03 & 0,14 & 2,95 & 0,22 & 5,5 & 0,10 & $156.007 .000,00$ & 0,00038 \\
\hline 19 & Sekunder JJ II & 3,21 & 0,22 & 3,25 & 0,25 & 6,9 & 0,13 & $59.379 .000,00$ & 0,00101 \\
\hline 20 & Sekunder 01 NGK I & 0,18 & 0,01 & 0,42 & 0,03 & 8,8 & 0,17 & $1.931 .000,00$ & 0,03107 \\
\hline 21 & Sekunder 02 NGK I & 1,86 & 0,13 & 1,85 & 0,14 & 19 & 0,36 & $2.551 .259 .000,00$ & 0,00002 \\
\hline 22 & Sekunder 03 NGK I & 3,83 & 0,26 & 4,25 & 0,32 & 18 & 0,34 & $1.516 .174 .000,00$ & 0,00004 \\
\hline 23 & Sekunder 01 NGK II & 0,42 & 0,03 & 0,63 & 0,05 & 9,6 & 0,18 & $44.607 .000,00$ & 0,00135 \\
\hline 24 & Sekunder 02 NGK II & 1,07 & 0,07 & 1,72 & 0,13 & 26 & 0,49 & $305.231 .000,00$ & 0,00020 \\
\hline 25 & Sekunder 03 NGK II & 2,68 & 0,18 & 2,05 & 0,16 & 17 & 0,32 & $695.626 .000,00$ & 0,00009 \\
\hline 26 & Sadap 01 GN & 2,83 & 0,20 & 3,25 & 0,25 & 16 & 0,30 & $2.109 .000,00$ & 0,02845 \\
\hline 27 & Drain Outlet $01 \mathrm{GN}$ & 1,67 & 0,11 & 2,20 & 0,17 & 1 & 0,02 & $924.000,00$ & 0,06494 \\
\hline 28 & Sadap 02 GN & 3,67 & 0,25 & 2,40 & 0,18 & 1,2 & 0,02 & $745.000,00$ & 0,08054 \\
\hline 29 & Sadap 01 BJ I & 1,43 & 0,10 & 0,35 & 0,03 & 4,2 & 0,08 & $2.741 .000,00$ & 0,02189 \\
\hline 30 & Sadap 02 BJ I & 1,52 & 0,10 & 1,20 & 0,09 & 4 & 0,08 & $1.622 .000,00$ & 0,03699 \\
\hline 31 & Drain Outlet $01 \mathrm{BJ} \mathrm{I}$ & 2,83 & 0,20 & 2,90 & 0,22 & 1,7 & 0,03 & $1.130 .000,00$ & 0,05310 \\
\hline 32 & Drain Outlet 02 BJ I & 0,83 & 0,06 & 1,00 & 0,08 & 9,6 & 0,18 & $1.130 .000,00$ & 0,05310 \\
\hline 33 & Sadap 03 BJ I & 0,83 & 0,06 & 1,00 & 0,08 & 2,7 & 0,05 & $1.130 .000,00$ & 0,05310 \\
\hline 34 & Sadap BJ II & 5,00 & 0,34 & 6,00 & 0,46 & 3,4 & 0,06 & $3.800 .000,00$ & 0,01579 \\
\hline 35 & Pelimpah Samping JJ I & 8,50 & 0,59 & 8,70 & 0,66 & 2,5 & 0,05 & $2.861 .000,00$ & 0,02097 \\
\hline 36 & Sadap JJ I & 8,50 & 0,59 & 12,50 & 0,95 & 5,5 & 0,10 & $2.385 .000,00$ & 0,02516 \\
\hline 37 & Sadap JJ II & 5,00 & 0,34 & 6,00 & 0,46 & 6,9 & 0,13 & $3.230 .000,00$ & 0,01858 \\
\hline 38 & Sadap 01 NGK I & 5,67 & 0,39 & 4,35 & 0,33 & 8,8 & 0,17 & $3.543 .000,00$ & 0,01693 \\
\hline 39 & Sadap 02 NGK I & 4,00 & 0,28 & 0,61 & 0,05 & 19 & 0,36 & $70.000,00$ & 0,85714 \\
\hline 40 & Sadap 03 NGK I & 1,67 & 0,11 & 1,50 & 0,11 & 18 & 0,34 & $953.000,00$ & 0,06296 \\
\hline 41 & Sadap 01 NGK II & 4,00 & 0,28 & 0,42 & 0,03 & 9,6 & 0,18 & $60.000,00$ & 1,00000 \\
\hline 42 & Sadap 02 NGK II & 8,33 & 0,57 & 8,33 & 0,63 & 26 & 0,49 & $2.850 .000,00$ & 0,02105 \\
\hline 43 & Sadap 03 NGK II & 4,00 & 0,28 & 0,42 & 0,03 & 17 & 0,32 & $156.000,00$ & 0,38462 \\
\hline 44 & Pembuangan GN & 4,29 & 0,30 & 3,70 & 0,28 & 0 & 0,00 & $131.688 .000,00$ & 0,00046 \\
\hline 45 & Pembuangan BJ I & 5,35 & 0,37 & 4,90 & 0,37 & 0 & 0,00 & $395.124 .000,00$ & 0,00015 \\
\hline 46 & Pembuangan BJ II & 3,60 & 0,25 & 4,90 & 0,37 & 0 & 0,00 & $184.064 .000,00$ & 0,00033 \\
\hline 47 & Pembuangan JJ I & 0,59 & 0,04 & 0,50 & 0,04 & 0 & 0,00 & $7.733 .000,00$ & 0,00776 \\
\hline 48 & Pembuangan JJ II & 1,47 & 0,10 & 1,00 & 0,08 & 0 & 0,00 & $12.823 .000,00$ & 0,00468 \\
\hline 49 & Pembuangan NGK I & 5,56 & 0,38 & 5,20 & 0,40 & 0 & 0,00 & $247.054 .000,00$ & 0,00024 \\
\hline 50 & Pembuangan NGK II & 4,99 & 0,34 & 4,90 & 0,37 & 0 & 0,00 & $180.933 .000,00$ & 0,00033 \\
\hline 51 & Talang 1 NGK I & 5,00 & 0,34 & 5,00 & 0,38 & 0,7 & 0,01 & $112.563 .000,00$ & 0,00053 \\
\hline & Maksimum & 14,50 & & 13,15 & & 52,6 & & & \\
\hline & Minimum & & & & & & & $60.000,00$ & \\
\hline
\end{tabular}


5. Prioritas Pemeliharaan

Proses selanjutnya adalah mengalikan matriks normalisasi dengan bobot masing - masing kriteria, dimana bobot kepentingan kriteria diperoleh dari hasil kuesioner dengan rincian sebagai berikut :

$\checkmark$ Bobot kondisi fisik $=0,35$

$\checkmark$ Bobot fungsi $=0,31$ $\checkmark$ Bobot luas layanan $=0,19$

$\checkmark$ Bobot biaya pemeliharaan $=0,15$

Sehingga diperoleh nilai prioritas yang ditunjukkan pada tabel 10

Tabel 10. Nilai Prioritas

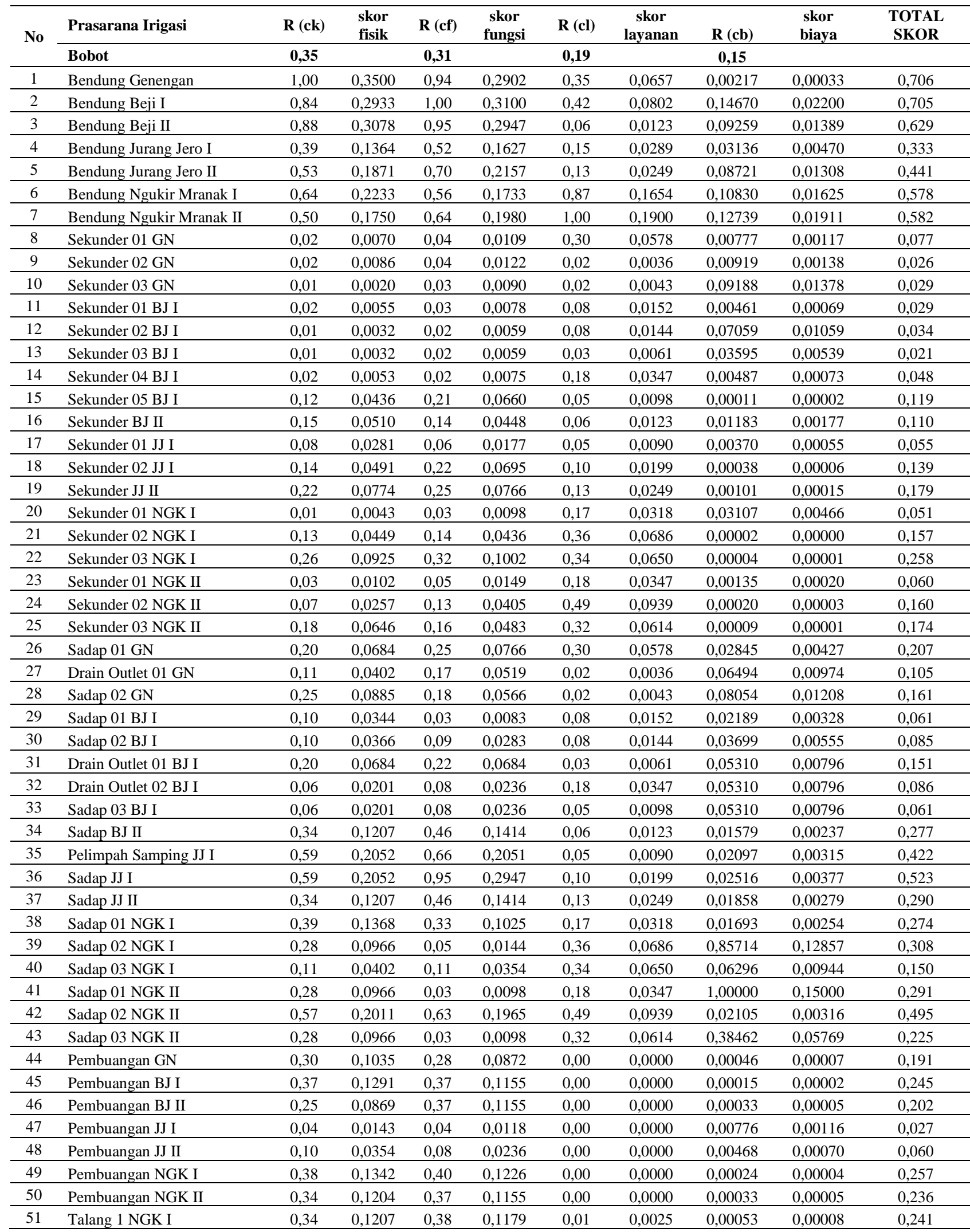


6. Ranking Prioritas Pemeliharaan Irigasi

Langkah terakhir adalah melakukan perankingan prioritas, yakni mengurutkan hasil prioritas dari yang terbesar sampai yang terkecil, seperti yang ditunjukkan pada Tabel 11 .

Tabel 11. Ranking Prioritas

\begin{tabular}{|c|c|c|}
\hline Prasarana Irigasi & Total Skor & Ranking \\
\hline Bendung Genengan & 0,706 & 1 \\
\hline Bendung Beji I & 0,705 & 2 \\
\hline Bendung Beji II & 0,629 & 3 \\
\hline Bendung Ngukir Mranak II & 0,582 & 4 \\
\hline Bendung Ngukir Mranak I & 0,578 & 5 \\
\hline Sadap JJ I & 0,523 & 6 \\
\hline Sadap 02 NGK II & 0,495 & 7 \\
\hline Bendung Jurang Jero II & 0,441 & 8 \\
\hline Pelimpah Samping JJ I & 0,422 & 9 \\
\hline Bendung Jurang Jero I & 0,333 & 10 \\
\hline Sadap 02 NGK I & 0,308 & 11 \\
\hline Sadap 01 NGK II & 0,291 & 12 \\
\hline Sadap JJ II & 0,290 & 13 \\
\hline Sadap BJ II & 0,277 & 14 \\
\hline Sadap 01 NGK I & 0,274 & 15 \\
\hline Sekunder 03 NGK I & 0,258 & 16 \\
\hline Pembuangan NGK I & 0,257 & 17 \\
\hline Pembuangan BJ I & 0,245 & 18 \\
\hline Talang 1 NGK I & 0,241 & 19 \\
\hline Pembuangan NGK II & 0,236 & 20 \\
\hline Sadap 03 NGK II & 0,225 & 21 \\
\hline Sadap 01 GN & 0,207 & 22 \\
\hline Pembuangan BJ II & 0,202 & 23 \\
\hline Pembuangan GN & 0,191 & 24 \\
\hline Sekunder JJ II & 0,179 & 25 \\
\hline Sekunder 03 NGK II & 0,174 & 26 \\
\hline Sadap 02 GN & 0,161 & 27 \\
\hline Sekunder 02 NGK II & 0,160 & 28 \\
\hline Sekunder 02 NGK I & 0,157 & 29 \\
\hline Drain Outlet 01 BJ I & 0,151 & 30 \\
\hline Sadap 03 NGK I & 0,150 & 31 \\
\hline Sekunder $02 \mathrm{JJ}$ I & 0,139 & 32 \\
\hline Sekunder 05 BJ I & 0,119 & 33 \\
\hline Sekunder BJ II & 0,110 & 34 \\
\hline Drain Outlet $01 \mathrm{GN}$ & 0,105 & 35 \\
\hline Drain Outlet $02 \mathrm{BJ}$ I & 0,086 & 36 \\
\hline Sadap 02 BJ I & 0,085 & 37 \\
\hline Sekunder 01 GN & 0,077 & 38 \\
\hline Sadap 03 BJ I & 0,061 & 39 \\
\hline Sadap 01 BJ I & 0,061 & 40 \\
\hline Sekunder 01 NGK II & 0,060 & 41 \\
\hline Pembuangan JJ II & 0,060 & 42 \\
\hline Sekunder $01 \mathrm{JJ}$ I & 0,055 & 43 \\
\hline Sekunder 01 NGK I & 0,051 & 44 \\
\hline Sekunder 04 BJ I & 0,048 & 45 \\
\hline Sekunder 02 BJ I & 0,034 & 46 \\
\hline Sekunder 01 BJ I & 0,029 & 47 \\
\hline Sekunder 03 GN & 0,029 & 48 \\
\hline Pembuangan JJ I & 0,027 & 49 \\
\hline Sekunder 02 GN & 0,026 & 50 \\
\hline Sekunder 03 BJ I & 0,021 & 51 \\
\hline
\end{tabular}

Tabel 11 menunjukkan rangking prioritas, dimana prasarana irigasi yang memiliki skor tertinggi menjadi prioritas utama pemeliharaan irigasi. Berdasarkan tabel diatas, menunjukkan bahwa prasarana irigasi yang menjadi prioritas pertama dalam kegiatan pemeliharaan irigasi Sub DAS Kali Brantas Kecamatan Junrejo Kota Batu adalah Bendung Genengan. Untuk prioritas kedua hingga lima berturut turut adalah Bendung Beji I, Bendung Beji II, Bendung Ngukir Mranak II dan Bendung Ngukir Mranak I.

\section{KESIMPULAN}

Berdasarkan hasil penelitian yang telah dilakukan maka dapat diambil beberapa kesimpulan sebagai berikut :

1. Kondisi fisik aset irigasi Sub DAS Kali Brantas Kota Batu masih dalam keadaan baik. Ada beberapa yang rusak ringan antara lain : Bendung Genengan, Bendung Beji I dan Bendung Beji II.

2. Keberfungsian aset irigasi Sub DAS Kali Brantas Kota Batu terkini hampir sama dengan penilaian kondisi fisik, yang perlu dilakukan pemeliharaan adalah: Bendung Genengan, Bendung Beji I, Bendung Beji II dan Bangunan Sadap Jurang Jero I.

3. Biaya pemeliharaan tertinggi pada saluran sekunder 02 Ngukir Mranak I dikarenakan panjangnya saluran yang masih berupa tanah yakni sebesar Rp 2.551.259.000,00. Biaya pemeliharaan terendah pada bangunan sadap 01 Ngukir Mranak I sebesar Rp. 60.000,00 berupa pengecatan pintu.

4. Ranking hasil prioritas pemeliharaan irigasi Sub DAS Kali Brantas Kota Batu dengan metode Simple Additive Weighting yang perlu dilakukan pemeliharaan aset irigasi yang pertama adalah Bangunan Utama (Bendung) Genengan. Untuk prioritas kedua hingga lima berturut - turut adalah ; Bendung Beji I, Bendung Beji II, Bendung Ngukir Mranak II dan Bendung Ngukir Mranak I. Sedangkan ranking prioritas berdasar jenis bangunan irigasi, sebagai berikut :

$\checkmark$ Bangunan Utama : Genengan

$\checkmark$ Saluran Pembawa : Saluran Sekunder 03 Ngukir Mranak I

$\checkmark$ Bangunan Bagi / Sadap : Bangunan Sadap Jurang Jero I

$\checkmark$ Saluran Pembuang : Saluran Pembuangan Ngukir Mranak I

$\checkmark$ Bangunan diatas saluran : Talang 01 Ngukir Mranak I

\section{DAFTAR PUSTAKA}

[1] Dep. Pekerjaan Umum (2012), "Permen $P U$ No.13/PRT/M/2012 tentang Pengelolaan Aset Irigasi”. Dep. Pekerjaan Umum, Jakarta.

[2] Pemerintah Republik Indonesia (2006), "PP No.20/2006 tentang Irigasi". Jakarta.

[3] Fakhrun, Diqy. (2017), "Analisis Perbandingan Metode AHP dan SAW dalam Penilaian Kinerja Karyawan". Jurnal LPKIA. Vol 1 No.1

[4] Kusumadewi, Sri., Hartati, S., Harjoko, A., Wardoyo, R. (2006), "Fuzzy Multi Attribute Decision Making (FUZZY MADM)”. Graha Ilmu, Yogyakarta 
[5] Direktorat Jenderal Pengairan. (1999). "Penilaian Jaringan Irigasi”. Departemen Pekerjaan Umum, Jakarta

[6] Dinas Pertanian Kota Batu. (2017). "Luas Layanan Jaringan Irigasi”. Dinas Pertanian. Kota Batu
[7] Dinas Pekerjaan Umum dan Penataan Ruang Kota Batu. (2017). "Analisa Harga Satuan Pekerjaan". Dinas Pekerjaan Umum dan Penataan Ruang. Kota Batu 